\title{
New record of Pterotaenia fasciata (Wiedemann) (Diptera, Ulidiidae) in Brazil, a probably mechanical vector of enteric bacteria
}

\author{
Anderson Sena Barnabe, Gabriel Zorello Laporta ${ }^{1}$, Marcia Zorello Laporta ${ }^{2}$ \& Carlos José Einicker Lamas ${ }^{3,4}$
}

${ }^{1}$ Departamento de Epidemiologia, Faculdade de Saúde Pública, Universidade de São Paulo. Avenida Dr. Arnaldo, 715, Cerqueira César, 01246-904 São Paulo-SP, Brasil. gabrielzorelo@usp.br

${ }^{2}$ Faculdade de Filosofia, Ciências e Letras, Centro Universitário Fundação Santo André, Avenida Príncipe de Gales, 821, Príncipe de Gales, 09060-650 Santo André-SP, Brasil. marcia.laporta@fsa.br

${ }^{3}$ Museu de Zoologia, Universidade de São Paulo, Avenida Nazaré, 481, Ipiranga, 04263-000 São Paulo-SP, Brasil.

${ }^{4} \mathrm{CNPq}$ fellowship.

\begin{abstract}
New record of Pterotaenia fasciata (Wiedemann) (Diptera, Ulidiidae) in Brazil, a probably mechanical vector of enteric bacteria. Pterotaenia fasciata is commonly recorded in rural areas in Argentina, but during a Diptera survey study developed in a reservoir which retains storm water from polluted canals in an urban area of Taboão da Serra municipality, SP, Brazil, we could capture P. fasciata adults. Enteric bacteria Escherichia coli T. Escherich, 1885 and Proteus sp. were isolated from $P$. fasciata collected in traps inside the reservoir and around it. Fecal coliforms and $E$. coli were found in the water of the reservoir. These records suggest that a high abundance of this species at urban areas with inadequate sewage canals should reveal these muscoid dipterans as mechanical vectors of enteric bacteria.
\end{abstract}

KEYWORDS. Microbiology; Neotropical; Parasitology; Taxonomy; Urbanization.

RESUMO. Novo registro de Pterotaenia fasciata (Wiedemann) (Diptera, Ulidiidae) no Brasil, um provável vetor mecânico de enterobactérias. Pterotaenia fasciata é encontrada freqüentemente em áreas rurais na Argentina, mas durante um estudo de levantamento de Diptera em um reservatório de retenção de enchentes em uma área urbana do município de Taboão da Serra, SP, Brasil, foram capturados adultos de P. fasciata. As enterobactérias Escherichia coli T. Escherich, 1885 e Proteus sp. foram isoladas de P. fasciata coletada em armadilhas no reservatório e em seu entorno. Coliformes fecais e E. coli foram encontrados na água do reservatório. Esses registros sugerem que a alta abundância dessa espécie em áreas urbanas sem saneamento básico poderia indicar esses dípteros muscóides como vetores mecânicos de enterobactérias.

PALAVRAS-CHAVE. Microbiologia; Neotropical; Parasitologia; Taxonomia; Urbanização.

Wiedemann (1830) described Pterotaenia fasciata, as Ortalis fasciata, briefly diagnosing the species by its black ground colour, whitish stripes on thorax, five blackish stripes on wings and bright whitish abdomen.

Steyskal (1968) recognized $P$. fasciata in family Otitidae. Nevertheless, the Diptera Site (2006) includes this species among the family Ulidiidae. The type-locality of $P$. fasciata is the city of Montevideo in Uruguay and the geographical distribution of the species is recorded to Bolivia, Uruguay, Argentina and Chile (Steyskal, 1968).

In laboratory, Arce de Hamity (1989) inferred that life cycle of $P$. fasciata from egg to adult was $70 \pm 11$ days. In this investigation, the adult life cycle ( $6 \pm 2$ days) in laboratory differed from life cycle ( $42 \pm 8$ days) of field collected adults, in Argentina. Immature stages breed in fruits and vegetal tissues decomposing its organic components, and then high abundance of $P$. fasciata in areas of land used to cultivate crops may be undesirable for a farmer.

According with Rey (2003), flies play a role as mechanical vectors in the transmission of pathogens to susceptible hosts.
The pathogens can be in fecal matter, biodegradable waste or others contaminated substrates where flies feed in and can carry these pathogens either on surface of its body or in its digestive system to another substrate which will be eaten by a susceptible host.

This communication aims to report the new record of $P$. fasciata in an urban environment, and also the first record of the species in Brazil.

The studied area was the TPI-4 reservoir which was constructed to retain storm water or rain runoff from canals that contain sewage in an urban area in Taboão da Serra, SP. TPI-4 structure has not been finished and its floor is covered by muddy soil. The TPI-4's maintenance was not done by municipal government between 2002 and 2004.

Traps for flies capture were used according with Ferreira (1978). Plastic traps with 50g of fresh fish inside were settled $1 \mathrm{~m}$ of height above the floor. Ten traps were settled on the TPI-4 floor and five were settled on the peridomiciliary environment nearby TPI- 4 . The traps were collected 48 hours later when atmospheric temperature was $26^{\circ} \mathrm{C}$ degrees. Twenty- 
one P. fasciata in TPI-4 and one nearby it were captured. Groups 1 and 2 formed each one by 7 specimens captured in TPI-4 were tested, respectively, with procedures of identification of the species and with a parasitological exam. Group 3 formed by 7 specimens captured in TPI-4 plus one specimen captured nearby it was tested with a microbiological exam.

The identification of the species was done by comparing the collected material with the specimens deposited in the Diptera collection of the Museu de Zoologia da Universidade de São Paulo.

At the parasitological laboratory, seven $P$. fasciata were anesthetized and each of them was put in a test tube with distillated water, and then these test tubes were set inside a centrifuge machine during two minutes with 1,500 revolutions per minute. The research for helminth eggs and protozoa cysts were carried out by means of optical microscopy analysis on the material precipitated inside the test-tube.

At the microbiological laboratory, eight $P$. fasciata were set on eight plates containing MacConckey agar medium for the isolation of enteric bacteria colonies. Lac + and Laccolonies isolated were submitted to specific biochemistry tests (EPM medium, MILi and citrate agar) for the identification of the species.

Three samples of water were collected inside TPI- 4 which had no drainage system working. $100 \mathrm{ml}$ of water were analyzed from each sample by means of the method of filtration in membrane with porous of $0,45 \mu \mathrm{M}$, put on plate with mTec agar medium (Difco), specific for research of fecal coliforms and enteric bacteria Escherichia coli T. Escherich, 1885. The samples were diluted 1/1000.

From all the P. fasciata collected during this survey, 21 (96 $\%)$ were captured inside TPI- 4 . The high temperature $\left(26^{\circ} \mathrm{C}\right)$ recorded has influenced fish decomposition that attracted the flies by chemical responses. It was a new record of $P$. fasciata in Brazil at an urbanized environment.

None helminth eggs and protozoa cysts were detected, but a larger sample must be necessary to really evaluate this data. E. coli and Proteus sp. were isolated from seven specimens of $P$. fasciata collected inside TPI-4 and one specimen of this species nearby it. Fecal coliforms and E. coli were found in all samples of water analyzed. E. coli and Proteus sp. are members of the order Enterobacteriales, facultatively anaerobic, gram-negative rods. Although considered common inhabitants of the intestinal tract of humans and other animals, these bacteria may be a cause of urinary infections or even intestinal diseases (Nataro \& Kaper, 1998; Trabulsi \& Alterthum, 2004). Finally, those results indicate that TPI-4 retains contaminated water with enteric bacteria and $P$. fasciata may carry them, as mechanical vectors, from inside TPI-4 to the peridomiciliary environment.

Acknowledgments. Special thanks for Dr. Angelo Pires do Prado of the Departamento de Parasitologia do Instituto de Biologia da Universidade Estadual de Campinas, Campinas, SP, for helping with the biology data and also for confirm species level determination of the species.

\section{REFERENCES}

Arce de Hamity, M. G. 1989. Morfologia de los estados inmaduros y aspectos biológicos de Pterotaenia fasciata (Wiedemann) (Diptera: Otitidae). Revista de la Sociedad Entomológica Argentina 45: $243-251$.

Diptera Site. 2006. BioSystematic Database of World Diptera. Accessed in January 14, 2006 at:[http//:www.sel.barc.usda.gov/ diptera/].

Ferreira, M. J. M. 1978. Sinantropia de dípteros muscoides de Curitiba, Paraná - I Calliphoridae. Revista Brasileira de Biologia 38: $445-454$.

Nataro J. P. \& J. B. Kaper. 1998. Diarrheagenic Escherichia coli. Clinical Microbiology Reviews 11: 142-201.

Rey L. 2002. Bases da Parasitologia Médica. Rio de Janeiro, Guanabara Koogan, 410 p.

Steyskal, G. C. 1968. Family Otitidae (Ortalidae, including Pterocallidae, Ulidiidae): 54. São Paulo: Museu de Zoologia da Universidade de São Paulo. p. 31. (A catalogue of the Diptera of the Americas - South of the United States).

Trabulsi, L. R. \& F. Alterthum. 2004. Microbiologia. São Paulo, Atheneu, $718 \mathrm{p}$.

Wiedemann, C. R. W. 1830. Aussereuropaische zweiflugelige Insekten. Zweiter Theil. Hamm, Schulze, xii +684 p.

Received 15/08/2006; accepted 19/01/2007 